\title{
Relationship between Concentration and Location of the Herbal Industry
}

\author{
Rohana Abd Rahman and Ariff Fahmi Abu Bakar \\ Economic and Strategic Analysis Programme, Forest Research Institute Malaysia, Kepong Selangor 52109, Malaysia
}

\begin{abstract}
Malaysia aspires to become developed and high income nation by year 2020. Under the Tenth Malaysia Plan, herbal industry was the first Entry Point Project for Agricultural National Key Economic Area in Economic Transformation Programme. To understand the current status of the herbal industry, FRIM (Forest Research Institute Malaysia) conducted the survey on 6,923 herbal chain players, consisted from upstream to downstream activities. A face-to-face interview was conducted using a structured questionnaire to gather the information. This paper highlighted the relationship between concentration of the herbal industry and urbanization's status of the areas. The finding shows that a statistically significant difference exists between category of herbal activities and status of the areas. The upstream activities are more concentrated in rural areas, while most of downstream activities in urban areas. It is in line with central place of theory on how settlements and places are located in relation to one another and their functions. Therefore, to further develop the herbal industry, the government should consider strategic location by category of industrial activities in policies planning, programmes implementation and providing infrastructural support needed by the industry.
\end{abstract}

Key words: Upstream, downstream, herbal industry, industrial location, central place theory.

\section{Introduction}

Malaysia is recognised as one of 12 top mega-biodiversity countries. Burkill [1] recorded around 1,300 plants used for traditional medicine in Malay Peninsula while Latif [2] reported around 2,000 plants with medicinal properties. The advantage aspired Malaysia to utilize its natural resources as sources of income and become developed nation by year 2020. Herbal industry was introduced as the first Entry Point Project for Agricultural National Key Economic Area in Economic Transformation Programme during the Tenth Malaysia Plan. The programme marks the government's seriousness in developing the Malaysian herbal industry as one of the major economic sectors [3].

The determination of the Malaysian government in developing the herbal industry is due to its economic potential. Global herbal medicine market is expected to reach 111 billion USD by end of 2023, projected to

Corresponding author: Rohana Abd Rahman, M.Sc., research fields: industry value chain, market intelligence, economic valuation. grow at a Compound Annual Growth Rate (CAGR) of around 7.2\% during 2017-2023 [4]. Local market potential on herbal products is also huge. Recent survey on herbal products consumption estimated $72 \%$ of Malaysian adults consumed herbal products [5]. The finding is almost similar to the previous survey conducted by FRIM in 2013 which records 73\% of herbal products consumption among Malaysian [6].

Study on business location especially on retail location has been explored long ago by researchers from various discipline. Clarke, et al. [7] in their paper explained the research tradition from the perspective of geographers and marketers in having a better understanding on the process of locational decision making. However, such studies on the Malaysian herbal industry are still lacking and it makes difficult to completely understand the distribution pattern of the industry.

\section{Methodology}

\subsection{Data Collection}

The data were originally acquired from study on 
value chain of herbal industry in Peninsular Malaysia. An extensive survey was conducted on the herbal industry players located throughout Peninsular Malaysia during 2014-2015. Updating of the first survey data (compiled in database known as HerbaXpress) was done from time to time starting 2016 until 2018 through different studies.

\subsection{Data Analysis}

Classification of urban, sub-urban and rural areas was done by referring to the delimitation provided by local authorities. Each of herbal player addressed was paired according to the respective group. Descriptive and independent samples Kruskal-Wallis Test were conducted to analyse the data.

\section{Results and Discussion}

The herbal industry players were formed with the group of PMS (Planting Material Suppliers), cultivators, product owners/manufactures, wholesalers and retailers. Most of herbal chain players operated in urban areas followed by sub-urban and finally rural. An average of 142 players distributed in each of 23 urban areas were identified in this study. A statistically significant difference $(H=20.891, p<$
0.01 ) exists between overall number of herbal chain players by status of the area. The distributions were most likely influenced by group of downstream players as the group formed the majority (88\%) of herbal chain players (Table 1).

Upstream players in herbal industry included group of PMS and cultivators. Three hundred and twenty-nine $(329,48 \%)$ of upstream players operated their business in rural areas while 248 (37\%) operated in sub-urban areas. Only 101 (15\%) of the upstream players operated in the urban areas. A statistically significant difference $(\mathrm{H}=7.279, \mathrm{p}<0.026)$ exists between number of upstream players by status of the areas (Table 2).

Selection of suitable and strategic business location is crucial in production of products. Most of producers preferred sub-urban or urban areas to locate their business. Only $128(23 \%)$ of producers decided to operate their business in rural areas. A statistically significant difference $(H=8.979, p<0.011)$ exists between number of producers by status of the areas (Table 3).

Downstream players consist group of wholesalers and retailers. It is common for downstream players with outlets to set up their business in middle of

Table 1 Herbal chain players by status of the areas.

\begin{tabular}{|c|c|c|c|c|c|c|c|c|}
\hline & \multirow{2}{*}{$N$} & \multirow{2}{*}{ Mean } & \multirow{2}{*}{$\begin{array}{l}\text { Std. } \\
\text { deviation }\end{array}$} & \multirow{2}{*}{ Std. error } & \multicolumn{2}{|c|}{$95 \%$ Confidence interval for mean } & \multirow{2}{*}{-Minimum } & \multirow{2}{*}{ Maximum } \\
\hline & & & & & Lower bound & Upper bound & & \\
\hline Urban & 23 & 142.22 & 179.772 & 37.485 & 64.48 & 219.96 & 3 & 657 \\
\hline Sub-urban & 32 & 79.19 & 67.406 & 11.916 & 54.89 & 103.49 & 14 & 256 \\
\hline Rural & 47 & 32.66 & 19.057 & 2.780 & 27.06 & 38.26 & 1 & 87 \\
\hline Total & 102 & 71.96 & 102.269 & 10.126 & 51.87 & 92.05 & 1 & 657 \\
\hline
\end{tabular}

$H=20.891^{* *}, p$-value $=0.000$.

** Independent-samples Kruskal-Wallis Test is significant at the 0.01 level (2-tailed).

Table 2 Upstream players by status of the areas.

\begin{tabular}{|c|c|c|c|c|c|c|c|c|c|}
\hline & \multirow{2}{*}{$N$} & \multirow{2}{*}{ Sum } & \multirow{2}{*}{ Mean } & \multirow{2}{*}{$\begin{array}{l}\text { Std. } \\
\text { deviation }\end{array}$} & \multirow{2}{*}{ Std. error } & \multicolumn{2}{|c|}{$95 \%$ Confidence interval for mean } & \multirow{2}{*}{-Minimum } & \multirow{2}{*}{ Maximum } \\
\hline & & & & & & Lower bound & Upper bound & & \\
\hline Urban & 23 & 101 & 4.3913 & 7.17786 & 1.49669 & 1.2874 & 7.4952 & 0.00 & 22.00 \\
\hline Sub-urban & 32 & 248 & 7.7500 & 9.53432 & 1.68545 & 4.3125 & 11.1875 & 0.00 & 48.00 \\
\hline Rural & 47 & 329 & 7.0000 & 9.76017 & 1.42367 & 4.1343 & 9.8657 & 0.00 & 60.00 \\
\hline Total & 102 & 678 & 6.6471 & 9.17125 & 0.90809 & 4.8457 & 8.4485 & 0.00 & 60.00 \\
\hline
\end{tabular}

$H=7.279^{*}, p$-value $=0.026$.

* Independent-samples Kruskal-Wallis Test is significant at the 0.05 level (2-tailed). 
Table 3 Number of producers by status of the areas.

\begin{tabular}{|c|c|c|c|c|c|c|c|c|c|}
\hline & \multirow{2}{*}{$N$} & \multirow{2}{*}{ Sum } & \multirow{2}{*}{ Mean } & \multirow{2}{*}{$\begin{array}{l}\text { Std. } \\
\text { deviation }\end{array}$} & \multirow{2}{*}{ Std. error } & \multicolumn{2}{|c|}{ 95\% Confidence interval for mean } & \multirow{2}{*}{ Minimum } & \multirow{2}{*}{ Maximum } \\
\hline & & & & & & Lower bound & Upper bound & & \\
\hline Urban & 23 & 206 & 8.9565 & 14.66126 & 3.05708 & 2.6165 & 15.2965 & 0.00 & 66.00 \\
\hline Sub-urban & 32 & 214 & 6.6875 & 6.18759 & 1.09382 & 4.4566 & 8.9184 & 0.00 & 23.00 \\
\hline Rural & 47 & 128 & 2.7234 & 2.98330 & 0.43516 & 1.8475 & 3.5993 & 0.00 & 15.00 \\
\hline Total & 102 & 548 & 5.3725 & 8.32855 & 0.82465 & 3.7367 & 7.0084 & 0.00 & 66.00 \\
\hline
\end{tabular}

$H=8.979^{*}, p$-value $=0.011$.

* Independent-samples Kruskal-Wallis Test is significant at the 0.05 level (2-tailed).

Table 4 Number of downstream players by status of the areas.

\begin{tabular}{|c|c|c|c|c|c|c|c|c|c|}
\hline & \multirow{2}{*}{$N$} & \multirow{2}{*}{ Sum } & \multirow{2}{*}{ Mean } & \multirow{2}{*}{$\begin{array}{l}\text { Std. } \\
\text { deviation }\end{array}$} & \multirow{2}{*}{ Std. error } & \multicolumn{2}{|c|}{$95 \%$ Confidence interval for mean } & \multirow{2}{*}{-Minimum } & \multirow{2}{*}{ Maximum } \\
\hline & & & & & & Lower bound & Upper bound & & \\
\hline Urban & 23 & 2,964 & 128.8696 & 162.71121 & 33.92763 & 58.5080 & 199.2312 & 3.00 & 626.00 \\
\hline Sub-urban & 32 & 2,072 & 64.7500 & 60.51180 & 10.69708 & 42.9332 & 86.5668 & 2.00 & 232.00 \\
\hline Rural & 47 & 1,078 & 22.9362 & 13.30806 & 1.94118 & 19.0288 & 26.8436 & 1.00 & 67.00 \\
\hline Total & 102 & 6,114 & 59.9412 & 93.26231 & 9.23434 & 41.6227 & 78.2596 & 1.00 & 626.00 \\
\hline
\end{tabular}

$H=25.718^{* *}, p$-value $=0.000$.

** Independent-samples Kruskal-Wallis Test is significant at the 0.01 level (2-tailed).

location with high population. Hence, it is not surprising when 5,036 or $82 \%$ of downstream players operated their business either in urban or sub-urban areas. A statistically significant difference $(\mathrm{H}=$ 25.718, $\mathrm{p}<0.00$ ) exists between number of downstream players by status of the areas (Table 4).

\section{Conclusion}

The finding shows that a statistically significant difference exists between category of herbal activities and status of the areas. The upstream activities (supplying of planting materials and cultivations) are more concentrated in rural areas, while most of downstream activities (wholesaling and retailing) in urban areas. Deciding location in operating a business is important to the business owners. Theoretically, business locations have a direct impact on the operating costs and revenues. The findings are also in line with the Christaller's Central Place Theory (1933) on how settlements and places are located in relation to one another and their functions. The theory discussed concepts of central place, central goods and services, the range of a goods and finally the complementary region [8].

Even though the herbal industry has been developed for a long time, recent study from FRIM concluded the industry is still in infancy stage [9]. Farizah et al. [3] also highlighted several issues and challenges that curb the production of locally high-claim herbal products. These situations proved the needs of continued government assistances to further strengthen the industry. However, proper strategies need to be outlined to ensure the benefits from government programmes reach the targeted groups. Therefore, to further develop the herbal industry, the government should consider strategic location by category of industrial activities as one of the important criteria in policies planning, programmes implementation and providing infrastructural support needed by the industry.

\section{Acknowledgement}

This study was conducted by FRIM and funded by Ministry of Agriculture and Agro-Based Industry, Malaysia.

\section{References}

[1] Burkill, I. H. 1966. A Dictionary of the Economic Products of the Malay Peninsula. Kuala Lumpur: Ministry of Agriculture and Co-operatives.

[2] Latif, A. 1997. "Medicinal and Aromatic Plants of Asia: Approaches." In Proceedings of the Symposium State-of-the-Art Strategies and Technologies for 
Conservation of Medicinal and Aromatic Plants, Kuala Lumpur, pp. 20-31.

[3] Farizah, A., Mohd Azlan, S. Z., Noorasiah, S., and Fadzilah Adibah, A. M. 2015. "Issues and Challenges in the Development of the Herbal Industry." In Prosiding PERKEM 10. Melaka: Universiti Kebangsaan Malaysia (UKM), pp. 227-38.

[4] Reauters Brand Feature. Accessed April 12, 2018. https://www.reuters.com/brandfeatures/venture-capital/art icle? $\mathrm{id}=32992$.

[5] Nurul'Afifah, S., Ali, A., Tan, C. L., Abubakar, I. J., Lua, P. L., et al. 2017. "Consumption of Herbal Products: A Study of Urban Community Survey." Australasian Medical Journal $10 \quad$ (2): $124-31$. doi:https://doi.org/10.21767/AMJ.2017.2797.

[6] Siti Zubaidah, S., Rohana, A. R., Lim, H. F., and Rosniza,
R. 2016. Consumer Preferences on Herbs and Herbal-Based Products in Peninsular Malaysia. Kepong, Selangor: Forest Research Institute Malaysia (FRIM).

[7] Clarke, I., Bennison, D., and Pal, J. 1997. "Toward a Contemporary Perspective of Retail Location." International Journal of Retail \& Distribution Management 25 (2): 59-69.

[8] Getis, A., and Getis, J. 1966. "Christaller's Central Place Theory." Journal of Geography 65 (5): 220-6. doi:10.1080/00221346608982415.

[9] Rohana, A. R., Siti Zubaidah, S., Ariff Fahmi, A. B., Nik Zanariah, N. M., and Lim, H. F., eds. 2017. Socio-economic Background of Herbal Industry in Peninsular Malaysia. Kepong, Selangor: Forest Research Institute Malaysia (FRIM). 